\title{
Analisis Daya Saing Ekspor Lada Juga Pengaruhnya Bagi Cadangan Devisa di 5 negara Pengekspor Utama Lada (Studi Kasus Indonesia, Malaysia, Vietnam, Brazil dan India)
}

\author{
Nuriman Ramadhani ${ }^{* a}$, Murtala ${ }^{* b}$, Fanny Nailufar ${ }^{* c}$, Yurina ${ }^{* d}$ \\ *Fakultas Ekonomi dan Bisnis Universitas Malikussaleh \\ a Corresponding author: nurimanramadhani8@gmail.com \\ b murtala@unimal.ac.id \\ c fannynailufar@unimal.ac.id \\ dyurina@unimal.ac.id
}

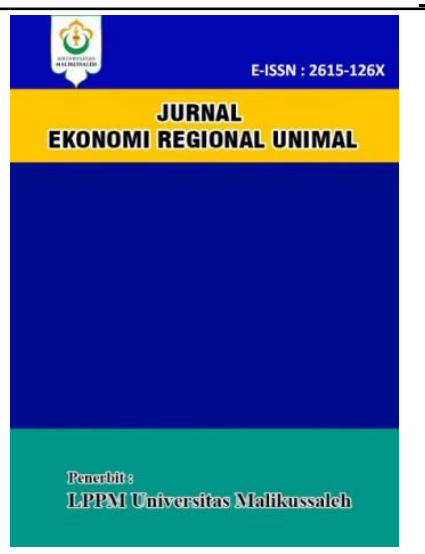

\section{A R T I C L E I N F O R M A T I O NA B S T RA C T}

\section{Keywords:}

Pepper Exports, Foreign Exchange

Reserves, Competitiveness,

Revealed Comparative Advantage

(RCA), and Autoregressive

Distributed Lag (PARDL) Panel.
This study aims to analyze the level of export competitiveness of pepper and its effect on foreign exchange reserves in the 5 main exporting countries of pepper (a case study in Indonesia, Malaysia, Vietnam, Brazil, and India). The analysis model used is Revealed Comparative Advantage (RCA) and the Panel Autoregressive Distributed Lag (PARDL) method. The results of the analysis in this study with the RCA index show that Vietnam is the largest exporter of pepper with an RCA index value of 1.2631, followed by Brazil with an RCA value of 1.136. For countries, Indonesia, Malaysia, and India still below average competitiveness and still have to increase their pepper exports. Furthermore, the analysis using PARDL shows that in the long term, the pepper export has a positive and significant effect on foreign exchange reserves with probability $(0.000<0.05)$, but the pepper export has no positive and insignificant effect on foreign exchange reserves with the probability of $0.3577>0.05$ ).

\section{PENDAHULUAN}

Cadangan devisa ialah suatu indikator moneter yang memiliki peran penting dalam menunjukkan kuat atau lemahnya fundamental perekonomian yang ada pada suatu negara. Selain itu jumlah cadangan devisa yang cukup memadai menjadi satu jaminan terwujudnya stabilitas moneter dan perekonomian makro suatu negara (Agustina, 2014)

Devisa yang dimilki setiap negara sangatlah penting, karena dengan adanya cadangan devisa mampu melancarkan transaksi atau kegiatan internasional, dan banyaknya cadangan devisa memberikan gambaran keadaan negara yang stabil, maka dari itu semua negara terutama negara berkembang seperti Indonesia, Malaysia, Vietnam, Brazil, dan India memilki tingkat cadangan devisa yang berbeda-beda. Adapun perkembangan cadangan devisa kelima negara tersebut dalam kurun waktu 2010 hingga 2017 yaitu sebagai berikut :
Tabel 1.1

Perkembangan Cadangan Devisa di Indonesia, Malaysia, Vietnam, Brazil, dan India (Milyar US\$)

\begin{tabular}{|c|r|r|r|r|l|}
\hline Tahun & \multicolumn{1}{|c|}{ Indonesia } & \multicolumn{1}{c|}{ Malaysia } & Vietam & Brazil & India \\
\hline 2010 & 92.908 & 104.884 & 12.466 & 118.056 & 125.277 \\
\hline 2011 & 108.539 & 131.780 & 13.539 & 120.356 & 127.285 \\
\hline 2012 & 110.837 & 137.784 & 25.573 & 126.566 & 124.587 \\
\hline 2013 & 96.364 & 133.444 & 25.893 & 120.214 & 126.493 \\
\hline 2014 & 108.836 & 114.572 & 34.189 & 122.965 & 130.455 \\
\hline 2015 & 103.268 & 93.979 & 28.250 & 121.175 & 131.311 \\
\hline 2016 & 113.493 & 93.122 & 37.728 & 125.505 & 132.145 \\
\hline 2017 & 113.922 & 89.877 & 41.318 & 125.686 & 133.917 \\
\hline
\end{tabular}

Berdasarkan tabel 1.1 terlihat bahwa tingkat cadangan devisa yang dimiliki setiap negara berbeda, ada sebagian negara yang memiliki pertumbuhan devisa yang tinggi seperti negara India degan cadangan devisa tahun 2010 tercatat sebesar US\$ 125.277 Milyar lebih besar dibanding dengan negara pengekspor lada lainnya, sedangkan ditahun yang sama Indonesia memiliki cadangan devisa hanya sebesar US\$ 92.908 milyar, dan jumlah ini merupakan yang paling rendah diantara negara lainnya. Namun ditahun berikutnya mulai 
mengalami perubahan hingga tahun 2017 negara Malaysia mengalami penurunan cadangan devisa yang tajam menjadi sebesar US\$ 89.877 milyar, angka ini lebih rendah dari pada tahun sebelumnya. Sedangkan negara Vietnam mulai mengalami peningkatan pada cadangan devisa dan tercatat memiliki devisa negaranya ditahun 2017 sebesar US\$ 41.318 milyar. Begitu juga halnya dengan negara Brazil yang tidak tertinggal dengan cadangan devisa yang cukup tinggi tercatat sebesar US\$ 125.686 Milyar.

Pada intinya setiap negara selalu berupaya dalam meningkatkan cadangan devisa negaranya, berbagai kegiatan yang mampu menambah masukkan devisa akan dilakukan setiap negara termasuk salah satunya yaitu kegiatan Ekspor. Ekspor adalah kegiatan penjualan hasil produk dalam negeri berupa barang dan jada untuk negara lain. Atau dapat diartikan ekspor adalah kegiatan tentang produksi barang dan jasa yang diproduksi disuatu negara untuk diperjualkan di luar batas negara tersebut. (Ustriaji Farid, 2016)

Ada banyak jenis ekspor yang mampu dilakukan setiap negara tergantung dari sumber daya apa yang dimiliki negara tersebut. Sumber daya alam yang seringkali diekspor adalah berasal dari jenis komoditas pertanian dan pertambangan (Tambunan, 2001). Hingga saat ini sektor pertanian masih menjadi salah satu sektor yang memberikan kontribusi tinggi bagi pertumbuhan ekonomi suatu negara. Pada negara berkembang yang memiliki daerah yang subur menunjukkan bahwa sub sektor perkebunan masih menjadi yang terdepan dalam sektor pertanian, artinya sub sektor ini memiliki beberapa komoditas unggulan yang memiliki kemampuan dan potensi besar dalam menyumbangkan kontribusinya terhadap cadangan devisa negara salah satunya adalah lada.(Yurike, 2017)

Lada merupakah salah satu rempah-rempah terlangka dan tertua yang memiliki nilai jual yang tinggi dipasar internasional (Athiyah, 2018) Perdagangan lada dunia semakin lama semakin meningkat, hal ini ditandai dengan semakin tingginya permintaan lada oleh negara lain di berbagai negara di dunia (Marlinda, 2008)

Menurut data (UN COMTRADE, 2017) dalam (Yurike, 2017) pada tahun 2015, negara eksportir utama lada di dunia adalah Vietnam, Brazil, Indonesia, Malaysia, serta India. Indonesia memiliki kontribusi ekspor ke negara tujuannya di dunia sebesar $16,43 \%$ dari total volume ekspor lada dunia yang dikalahkan oleh Vietnam dengan kontribusinya sebesar 33,79\% dan mengugguli dari Malaysia yang kontribusinya hanya $3,71 \%$. Namun dari kelima negara tersebut hanya ada beberapa negara yang memiliki keunggulan dalam ekspor ladanya. Namun setiap negara pengekspor utama lada memiliki jumlah ekspor lada yag berbeda setiap negaranya, adadpun perkembangan ekspor lada dapat dilihat pada tabel dibawah ini :

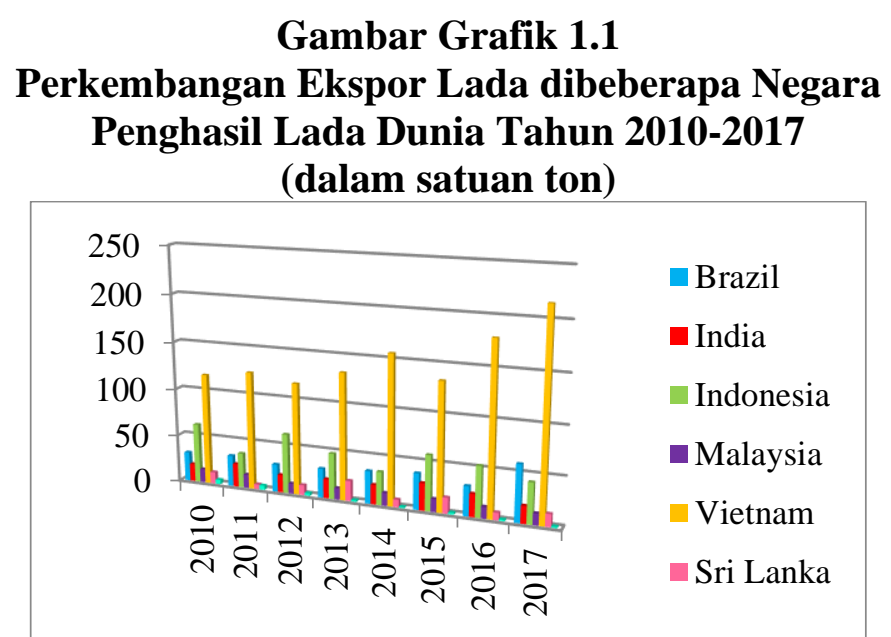

Sumber : IPC, data diolah (2020)

Berdasarkan gambar pada grafik 1.1 diatas terlihat bahwa selama kurun waktu 2010-2017 perkembangan ekspor diantara negara pengekspor utama lada menunjukkan bahwa negara yang paling banyak melakukan ekpor atau menjadi negara pengekspor terbesar diantara negara lain yait negara Vietnam dengan total ekspor mencapai 1.399.338 Ton. Sedangkan negara lain seperti Indonesia berada pada urutan kedua dengan total ekspor mencapai 501.245 Ton. Dan disusul negara Brazil dengan jumlah ekspor mencapai 358.348 Ton. Selanjutnya negara india tercatat dengan total ekspor sebesar 220.422 Ton dan pada urutan terakhir yaitu negara Malaysia dengan total ekspornya sebesar 128.444 Ton.

Faktor penting dalam menentukan ekspor yaitu kemampuan negara tersebut untuk mengeluarkan barang-barang yang dapat bersaing dalam pasaran luar negeri. (Dananjaya Baskara, jayawarsa, 2019) Setiap negara yang melakukan ekspor harus mampu bertahan dalam persaingan pasar internasional. Oleh karena itu selain memiliki tingkat ekspor yang tinggi maka tingkat daya saing juga sangat penting dimiliki setiap negara pengekspor.

Ekspor memiliki hubungan yang sangat erat dengan cadangan devisa karena dari hasil kegiatan ekspor nantinya akan diterima sejumlah uang pembayaran berupa Valas (valuta asing) yang aka masuk dalam rekening devisa negara, sehingga apabila ekspor meningkat maka cadangan devisa juga akan meningkat. (Ridho, 2015). 
Penelitian ini bertujuan untuk melihat tingkat daya saing ekspor lada di lima negara pengekspor utama lada dan untuk melihat bagaimana kontribusi ekspor lada terhadap cadangan devisa di masing-masing negara pengekspor lada. Beberapa penelitian terdahulu yang menyatakan adanya hubungan ekspor dengan cadangan devisa diantaranya penelitian (Apsari, 2018) dan (Hani Zaun, Pujiantio Agung, 2016) yang menyebutkan bahwa ekspor lada mempunyai pengaruh terhadap cadangan devisa.

Pembahasan kedua dalam penelitian ini akan mengkaji tetang tinjauan teoritis, lalu pada bagian ketiga akan dibahas metode penelitian, pada bagian keempat akan dibahas hasil dan penelitian, bagian kelima atau terakhir akan dibahas kesimpulan dan rekomendasi.

\section{TINJAUAN TEORITIS}

\section{Cadangan Devisa}

(Asmanto \& Suryandari, 2008) menyatakan bahwa asset- asset berharga yang dimiliki suatu negara dan nilainya diakui dan diterima oleh semua masyarakat internasional, juga dapat dipakai untuk alat-alat pembayaran yang sah bagi pemerintah atau negara ketika melakukan transaksi beserta pembayaran internasional dinamakan Cadangan Devisa. Cadangan devisa juga memiliki peran penting dalam mendorong kemajuan ekonomi suatu negara serta sebagai kekuatan suatu negara dalam menghadapi persaingan global.

Cadangan devisa merupakan bagian dari tabungan nasional yang mana pertumbuhan dan perubahan tinggi rendahnya cadangan devisa adalah sinyal bagi pasar keuangan internasional tentang kredibilitas kebijakan moneter dan kelayakan kredit suatu negara. Apabila cadangan devisa bertanda (+) maka dapat diartikan terjadi peningkatan, sedangkan apabila bertanda (-) maka terjadi pengurangan pada cadangan devisa. (Gandhi , Virgoana, 2006)

(Pinem, 2009) menyebutkan bahwa sumber cadangan devisa yang dimiliki suatu negara pada umumnya terdiri dari dua yaitu sumber dari dalam negeri misalnya hasil penjualan ekspor barang maupun jasa yang dimiliki negara tersebut, laba dari investasi asing milik warga negara indonwsia, hasil kegiatan parawisata internasional, dll. Sedangkan sumber cadangan devisa yang berasal dari luar negeri diantaranya utang atau pinjamanan luar negeri, hadiah dari badan atau lembaga seperti PBB dan lainnya.

\section{Ekspor}

Ekspor adalah penjualan antara dua negara yang mampu memberikan pengaruh agar dapat meningkatkan permintaan dalam negeri sehingga menimbulkan pabrik industri-industri besar, dan dapat memberikan dorongan dalam dinamika pertumbuhan perdagangan luar negeri yang nantinya negara berkembang bisa bersaing dengan negara-negara maju. (Asmara, 2018).

Menurut (Jimmy, 2013) dalam penelitiannya menyebutkan bahwa Ekspor adalah pembelian dari negara lain atas barang yang diproduksi oleh perusahaan-perusahaan di dalam negeri. Ekspor neto adalah selisih hasil antara total ekspor dengan total impor yang ada disuatu negara. Apabila angka ekspor neto positif, berarti nilai ekspor lebih tinggi dari nilai impor dan apabila nilai ekspor neto negatif, berarti nilai ekspor lebih rendah dari nilai impor (Case, 2007)

Teori Thomas Munn yang termasuk salah satu tokoh ekonomi klasik menyatakan bahwa perdagangan internasional akan menguntungkan neraca pembayaran internasional suatu negara apabila niai ekspor lebih tinggi dari nilai impor atau sering dirumuskan $(X>M)$. Melalui pandangan ini banyak negara terobsesi ingin membuka diri dan melaksanakan perdagangan internasional bahkan sampai memiliki target pencapaian yang sangat tinggi harus dapat memperluasan ekspor, kemudian kelebihan produksi dalam negeri juga diharapkan dapat diperdagangkan ke luar negeri sehingga menghasilkan keuntungan bagi negara tersebut, dari pada kelebihan barang justru hanya akan berdampak terhadap kelebihan barang dalam negeri yang mampu menjadikan inflasi dalam negeri semakin meningkat.(Mainah, 2016)

Sedangkan menurut (Athiyah, 2018) Lada didefinisikan sebagai tanaman rempah-rempah tertua dan terlangka yang memiliki nilai jual serta volume penjualan yang tinggi dibandingkan dengan rempah-rempah lainnya. Lada juga mempunyai nama julukan yaitu The King of Spice (raja rempahrempah). Sehingga dapat disimpulkan ekspor lada adalah kegiatan penjualan atau perdagangan tanaman lada untuk negara lain terutama negaranegara yang membutuhkan lada karena tidak mampu memproduksi di negaranya sendiri.

Daya saing dapat diartikan sebagai kemampuan yang dimiliki setiap negara dalam menawarkan produk dan layanan yang memenuhi standar kualitas, harga pasar dan nilai barang, baik didalam negeri maupun luar negeri serta mendapatkan keuntungan yang memadai sebagai pengganti sumber daya yang digunakan dalam proses produksi. (Satryana, Hardi, 2016) 
Menurut (Alamsyah Zulkifli, 2019) dalam penelitiannya menyebutkan bahwa meningkatnya daya saing yang terjadi pada suatu komoditas akan membuat meningkatnya keuntungan komparatif dalam memproduksi komoditas tersebut dan pendapatan akan meningkat seiring berjalannya waktu.

Selanjutnya (Nopirin, 2014) menyebutkan daya saing produk yang ada pada suatu negara sangat bergantung pada kemampuan negara yang tersebut dalam melakukan inovasi dan pengembangan produk yang dimiliki tersebut. Kemampuan suatu produk agar mampu menjadi komoditi ekspor unggulan juga tergantung dari keunggulan komparatif dan kompetitif yang dimiliki komoditi tersebut.

\section{Kerangka Konseptual}

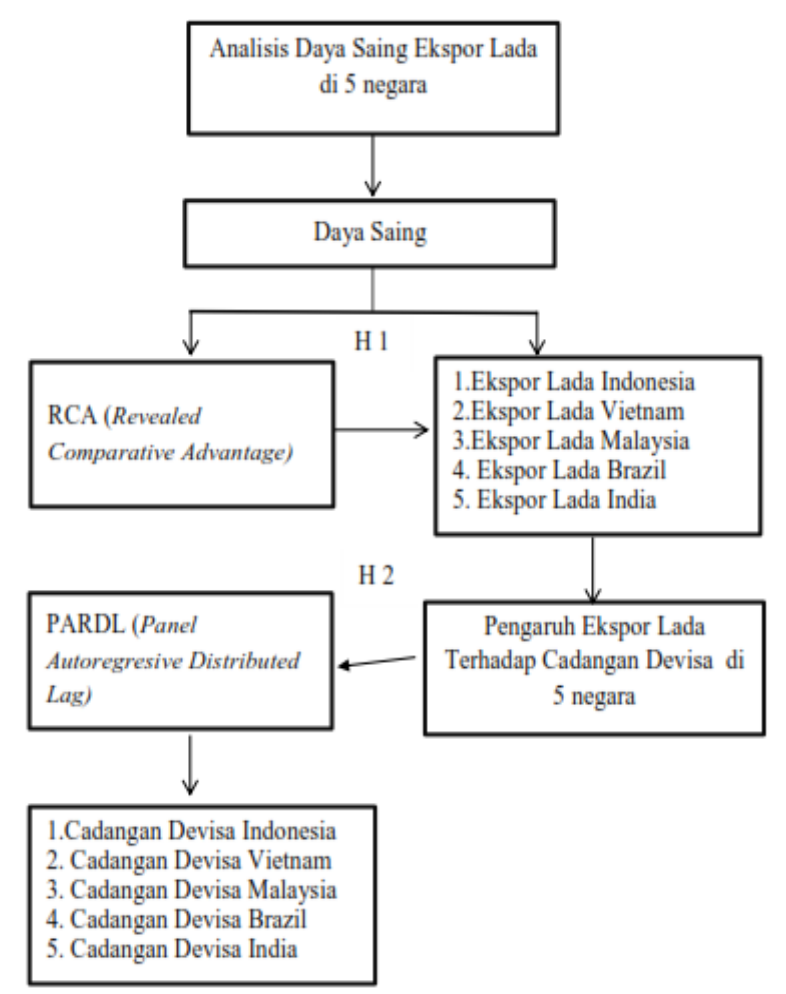

\section{Gambar 2.1 Kerangka Konseptual}

Kerangka konseptual pada gambar 2.1 di atas menjelaskan tingkat daya saing ekspor lada yang akan di ukur dengan menggunakan metode Revealed Comparative Advantage (RCA), selanjutnya untuk melihat kontrubusi dari ekspor lada terhadap cadangan devisa akan di ukur dengan metode Panel Autoregresive Distributed Lag (PARDL)

\section{Hipotesis}

Adapun hipotesis alternatif yang digunakan dalam penelitian ini adalah sebagai berikut :

$\mathrm{H}_{1}$ : Diduga ekspor lada di 5 negara pengekspor utama lada memiliki daya saing diatas ratarata

$\mathrm{H}_{2}$ : Diduga ekspor lada memiliki pengaruh terhadap cadangan devisa di 5 negara pengekspor utama lada.

\section{METODEPENELITIAN}

\section{Objek dan Lokasi Penelitian}

Objek yang digunakan dalam penelitian ini adalah tanaman Lada, Sedangkan Lokasi penelitian dipilih secara sengaja yaitu negara Indonesia, Vietnam, Malaysia, Brazil dan India, lima negara ini dipilih karena merupakan negara penghasil Ekspor komoditas Lada terbesar di Dunia.

\section{Jenis dan Sumber Data}

penelitian ini menggunakan jenis data adalah kuantitatif dengan pendekatan data panel dinamis yang merupakan gabungan data time series (20012017) dan cros section (5 negara) dalam bentuk model dinamis.

Selanjutnya dalam penelitian ini diperoleh sumber data melalui instansi atau pusat data secara online seperti International Pepper Community (IPC), International Trade Center, Islamic Development Bank serta sumber lain seperti jurnal, tesis, dan hasil penelitian sebelumnya yang sesuai dan searah dengan penelitian ini.

\section{Definisi Operasionalisasi Variabel}

Berdasarkan rumusan hipotesis penelitian, variabel penelitian terdiri dari dua variabel yaitu Variabel Dependen dan Variabel Independen, yaitu sebagai berikut :

1. Cadangan Devisa (Y)

Cadangan devisa ialah aset yang dimiliki suatu negara disimpan pada bank sentral dan otoritas moneter, yang digunakan untuk pembayaran dalam transaksi luar negeri (ekspor-impor), dan pembayarannya dapat dibayarkan dengan menggunakan emas, mata uang negara asing atau valas, juga surat-surat berharga yang dimiliki suatu negara.

Idikator dalam cadangan devisa adalah Jumlah total Cadangan Devisa di 5 negara (Indonesia, Malaysia, Vietnam, Brazil, dan India) yang di diukur dengan satuan Milyar US\$.

2. Ekspor Lada $\left(\mathrm{X}_{1}\right)$

Ekspor adalah penjualan barang dan jasa ke luar negeri dengan menggunakan sistem pembayaran 
internasional, serta kualitas, kuantitas dan syarat penjualan lainnya yang telah disepakati oleh pihak eksportir dan importir. Idikator yang digunakan yaitu Jumlah Ekspor Lada di 5 negara pengekspor lada (Indonesia, Malaysia, Vietnam, Brazil, dan India) yang diukur dengan satuan Juta Ton.

\section{Metode Analisis Data}

\section{Revealed Comparative Advantage (RCA)}

(Munandar, 2010) menyatakan bahwa RCA adalah salah satu metode yang dinamis yang dapat digunakan untuk menganalisis tingkat daya saing. RCA banyak digunakan dalam penelitianpenelitian terdahulu dalam mengukur perubahan keunggulan komparatif suatu produk atau barang yang dimiliki suatu individu, kelompok, maupun negara. Secara sistematis rumus indeks RCA sebagai berikut:

$$
\text { Indeks } \operatorname{RCA}_{\mathrm{ij}}=\frac{\mathrm{X}_{\mathrm{ij}} / \mathrm{X}_{\mathrm{it}}}{\mathrm{W}_{\mathrm{j}} / \mathrm{W}_{\mathrm{t}}}
$$

Keterangan:

$\mathrm{Xij}=$ Nilai Ekspor Komoditi j dari negara $\mathrm{i}$

Xit $=$ Nilai Ekspor Total (produk j dan lainnya) negara $\mathrm{i}$

$\mathrm{Wj}=$ Nilai Ekspor Komoditi j di Dunia

$\mathrm{Wt}=$ Nilai Ekspor Total Dunia

Adapun ketentuan dalam menghitung nilai RCA yaitu apabila nilai RCA index $>1$, maka terdapat keunggulan komparatif atau memiliki daya saing yang tinggi terhadap suatu produk, dan apabila nilai RCA index $<1$, maka daya saing suatu produk sangat lemah. (Satryana, Hardi, 2016)

\section{Metode Panel Autoregressive Distributed Lag (PARDL)}

Metode Panel Auto Regressive Distributed Lag (PARDL) yaitu salah satu bentuk metode dinamis dalam ekonometrika, yang menggunakan gabungan data time series dan cros section (data panel). Metode ini mampu menjelaskan regresi dinamis dalam menganalisis hubungan jangka panjang yang melibatkan adanya uji kointegrasi diantara variabel-variabel penelitian. (Noaliana Ade, Sari Indah, Wahyu, 2018) ada beberapa tahapan dalam uji PADRL yaitu :

\section{Uji Stationeritas}

Ujistasioner menggunakan metode (unit root test) dilakukan untuk menganalisis apakah suatu variabel dalam penelitian stasioner atau tidak. Ketentuan uji stasioner dikatakan suatu variabel stasioner apabila nilai probabilitasnya dibawah $(<$ $0.05)$

Prosedur uji stasioner pada PARDL dari metode Levin, Lin \& Chu t, uji ADF - Fisher Chi-square, uji PP-Fisher Chi-square dengan salah satu syarat yg harus terpenuhi adalah stasioner pada tingkat First Different (1df). (Hidayat, 2018)

\section{Uji Panjang Lag}

(Apriyanto, 2016) mengatakan bahwa uji lag optimum dilakukan untuk mengetahui seberapa lama pengaruh suatu variabel terhadap variabel lainnya. Uji lag optimum juga berguna untuk menghindari adanya indikasi autokorelasi di dalam model. Pengujian panjang lag optimal dapat diuji dengan menggunakan beberapa kriteria seperti informasi Likehood Ratio (LR), Final Prediction Error (FPE), Akaike Information Critrion (AIC), Schwarz Information Critrion (SC) dan Hannan Quin Critrion (HQ). Lag optimum yang dipilih ditandai dengan tanda bintang (*) terbanyak yang berada pada lag angka tersebut.

\section{Uji Kointegrasi}

Kointegrasi adalah suatu pengujian dinami yang dilakukan untuk mengetahui ada tidaknya hubungan jangka panjang antara variabel-variabel penelitian. Pada model PARDL mensyaratkan minimal terdapat 2 variabel yang terkointegrasi. (Rahmat Hidayat,Irawan, 2018).

Pengujian kointegrasi dalam metode Panel Autoregressive Distributed Lag (PARDL) dilihat dari Panel Cointegration Test. Metode yang dapat digunakan untuk melakukan uji kointegrasi adalah KAO Residual Cointegration Test (Engle-Granger Based) untuk melihat terjadinya kointegrasi secara keseluruhan dan Johansen Fisher Panel Cointegration Test untuk melihat kointegrasi per variabel yang terdapat dalam software E-Views 10.

\section{Estimasi Panel Autoregressive Distributed Lag (PARDL)}

(Kamal, 2018) menyebutkan bahwa Persamaan Panel ARDL secara sistematis memiliki rumus yaitu :

$Y_{j, t}=\alpha_{0 i}+\sum_{i=1}^{n} \theta i Y_{j, t-i}+\beta^{\prime} X_{j, t-i}+\mu_{j, t} \ldots \ldots . .(1)$

Selanjutnya untuk memudahkan penelitian, maka peneliti meringkaskan persamaan penelitian 
yang lebih mudah dipahami sesuai dengan permasalahan yang diteliti, adapun rumusan persamaan penelitian ini jangka panjang sebagai berikut :

$\Delta \operatorname{CDV}_{\mathrm{j}, \mathrm{t}}=\sum_{\mathrm{i}=1}^{\mathrm{n}} \beta_{1} \mathrm{EKSP}_{\mathrm{j}, \mathrm{t}-1}+\mu_{\mathrm{j}, \mathrm{t}}$

Sedangkan dalam jangka pendek dapat dirumuskan sebagai berikut :

$\Delta \mathrm{CDV}_{\mathrm{j}, \mathrm{t}}=\alpha_{0 \mathrm{i}}+\sum_{i=1}^{n} \alpha 2 \mathrm{i} \Delta \mathrm{EKSP}_{\mathrm{j}, \mathrm{t}-1}+\mu_{\mathrm{j}, \mathrm{t}} \ldots \ldots$ (3)

Keterangan :

CDV = Cadangan Devisa (Milyar US\$)

EKSP $=$ Ekspor Lada (Juta Ton)

$\alpha_{0} \quad=$ Kostanta

$\alpha_{1}, \alpha_{2}=$ Koefisien Jangka Pendek

$\beta_{1} \quad=$ Koefisien Jangka Panjang

$\mathrm{j}=$ Jumlah Observasi (5 negara)

$\mathrm{t}=$ Banyaknya waktu (16 tahun, $2001 \mathrm{sd}$ 2017)

$\mathrm{i} \quad=$ Panjang Lag

$\mu \quad=$ error term

\section{Hasil Penelitian dan Pembahasan}

Hasil Revealed Comperatitive Advantage (RCA)

Berikut ini hasil perhitungan indeks RCA Ekspor lada di 5 negara Pengekspor Utama Lada tahun 2001-2017

Tabel 4.1

Nilai Indeks Revealed Comperatitive Advantage (RCA) Ekspor Lada Di 5 Negara Pengekspor Utama Lada Tahun 2001-2017

\begin{tabular}{|c|r|r|r|r|r|}
\hline \multirow{2}{*}{ Tahun } & \multicolumn{5}{|c|}{ RCA } \\
\cline { 2 - 6 } & Indonesia & Malaysia & Vietnam & \multicolumn{1}{c|}{ Brazil } & \multicolumn{1}{c|}{ India } \\
\hline 2001 & 1,3655 & 1,9758 & 0,5939 & 1,2508 & 1,2557 \\
\hline 2002 & 1,2087 & 1,6198 & 0,7399 & 1,1556 & 1,2300 \\
\hline 2003 & 1,4362 & 1,4168 & 0,7255 & 1,1995 & 0,8886 \\
\hline 2004 & 1,0503 & 1,3274 & 0,9172 & 1,2275 & 0,7314 \\
\hline 2005 & 0,8840 & 1,1965 & 1,0392 & 1,0481 & 0,8293 \\
\hline 2006 & 0,7553 & 1,0820 & 1,0124 & 1,1287 & 1,1947 \\
\hline 2007 & 0,8808 & 1,0628 & 0,7789 & 1,1309 & 2,1550 \\
\hline 2008 & 1,2052 & 0,9487 & 0,846 & 1,0541 & 1,3127 \\
\hline 2009 & 0,9891 & 0,7894 & 1,0755 & 0,9288 & 0,8892 \\
\hline 2010 & 1,3012 & 0,8958 & 0,9873 & 0,8467 & 0,7393 \\
\hline 2011 & 0,7841 & 0,9399 & 1,0917 & 0,9373 & 1,1255 \\
\hline 2012 & 1,3013 & 0,8058 & 0,9960 & 0,8076 & 0,8188 \\
\hline 2013 & 0,9732 & 0,8574 & 1,1062 & 0,8293 & 0,8757 \\
\hline 2014 & 0,6659 & 0,8225 & 1,2299 & 0,8758 & 0,8373 \\
\hline 2015 & 1,0624 & 0,7848 & 1,0027 & 0,9281 & 1,1169 \\
\hline 2016 & 0,8819 & 0,6418 & 1,2209 & 0,0887 & 0,8479 \\
\hline 2017 & 0,6114 & 0,5375 & 1,2631 & 1,1369 & 0,5596 \\
\hline Sumber : Data diolah, 2020 & & & & \\
\hline
\end{tabular}

Berdasarkan hasil pada tabel 4.1 diatas terlihat perhitungan indeks RCA bahwa negara Indonesia memiliki keunggulan komperatif dari tahun 2001, 2002, 2003, 2004, 2008, kemudian ditahun 2010, 2012, dan 2015. Negara Malaysia memiliki keunggulan komperatif mulai tahun 2001, 2002, 2003, 2004, 2005, 2006, dan 2007. Begitu juga pada negara Vietnam memiliki keunggulan komperatif pada tahun 2005, 2006, lalu ditahun 2009, 2011, 2013, 2014, 2015, 2016, dan 2017. Negara Brazil memiliki keunggulan komperatif ditahun 2001, 2002, 2003, 2004, 2005, 2006, 2007, 2008, dan 2017. Sedangkan negara India memiliki keunggulan komperatif pada tahun 2001, 2002, 2006, 2007, 2008, 2011, dan 2015.

Jika dilhat dari pemaparan diatas dapat disimpulkan dari ke 5 negara pengekspor utama lada, terdapat 3 negara yang menguasai pasar ekspor lada, ke 3 negara tersebut ialah negara Vietnam, Indonesia dan Brazil.

Tabel 4.2

Nilai Ekspor, Ranking Ekspor, Nilai RCA dan

Ranking RCA Pengekspor Lada di 5 Negara Pengekspor Utama Lada

\begin{tabular}{|c|c|c|c|c|c|}
\hline No & Negara & $\begin{array}{c}\text { Nilai Ekspor } \\
\text { (Ton) }\end{array}$ & $\begin{array}{c}\text { Ranking } \\
\text { Ekspor }\end{array}$ & $\begin{array}{c}\text { Nilai } \\
\text { RCA }\end{array}$ & $\begin{array}{c}\text { Ranking } \\
\text { RCA }\end{array}$ \\
\hline 1 & Indonesia & 826.485 & 2 & 0,6114 & 3 \\
\hline 2 & Malaysia & 268.365 & 5 & 0,5375 & 5 \\
\hline 3 & Vietnam & 2.015 .143 & 1 & 1,2631 & 1 \\
\hline 4 & Brazil & 619.581 & 3 & 1,1369 & 2 \\
\hline 5 & India & 386.078 & 4 & 0,5596 & 4 \\
\hline
\end{tabular}

Berdasarkan data pada tabel 4.2 diatas, dapat ditarik kesimpulan bahwa negara Vietnam merupakan negara pengekspor lada terbanyak di dunia selama periode waktu 2001-2017, hal ini terbukti dari total nilai ekspor lada Vietnam yaitu sebesar 2.015.143 Ton dengan peringkat rangking 1, kemudian disusul negaara Indonesia pada posisi peringkat ke 2 dengan nilai total ekspor ladanya mencapai 826.485 Ton, dan negara brazil yang menduduki peringkat ke 3 memiliki total nilai ekspor ladanya sebesar 619.581 Ton, sedangkan negara India berada pada peringkat ke 4 yang memiliki nilai ekspor lada total sebanyak 386.078 Ton, dan negara Malaysia dengan total nilai ekspor sebesar 268.365 Ton menduduki posisi terkahir atau ke 5 .

Apabila dilihat dari keunggulan komperati yang dimiliki 5 negara tersbut, maka didapat keunggulan komperatif ekspor lada di negara Vietnam lebih baik dan lebih unggul dibandingkan negara Brazil dan Indonesia, hal ini dilihat dari nilai RCA yang diperoleh negara Vietnam sebesar 1.2631, selanjutnya negara Brazil dengan niai RCA sebesar 1.1369, negara Indonesia sebesar 0,6114, negara India sebesar 0.5596 dan negara Malaysia sebesar 0.5375. Kemudian negara Vietnam juga menududuki peringkat pertama nilai RCA, yang 
disusul Brazil pada peringkat kedua, Indonesia diperingkat ketiga, negara India peringkat keempat dan peringkat kelima diduduki oleh negara Brazil.

\section{Hasil Panel Autoregressive Distributed Lag (PARDL)}

\section{Uji Stasioner}

Hasil uji stasioner dengan uji root test yang menggunakan metode Levin, Lin \& Chu $t^{*}$, Augmanted Dickey Fuller (ADF)- Fisher Chisquare, dan PP - Fisher Chi-square dapat dilihiat pada tebel dibawah ini:

Tabel 4.3

\section{Hasil Uji Stasioner Panel Unit Root test}

\begin{tabular}{|l|c|c|l|r|c|}
\hline \multicolumn{2}{|c|}{$\begin{array}{l}\text { Variabel : Cadangan Devisa } \\
\text { (Level) }\end{array}$} & \multicolumn{3}{c|}{$\begin{array}{r}\text { Variabel : Ekspor Lada } \\
\text { (level) }\end{array}$} \\
\hline Method & Statistic & Prob. & Method & Statistic & Prob. \\
\hline $\begin{array}{l}\text { Levin, Lin \& } \\
\text { Chu t* }\end{array}$ & 2,53343 & 0,9944 & $\begin{array}{l}\text { Levin, Lin \& } \\
\text { Chu t* }\end{array}$ & $-2,51641$ & 0,0059 \\
\hline $\begin{array}{l}\text { ADF - Fisher } \\
\text { Chi-square }\end{array}$ & 1,16470 & 0,9977 & $\begin{array}{l}\text { ADF -Fisher } \\
\text { Chi-square }\end{array}$ & 16,86680 & 0,0747 \\
\hline $\begin{array}{l}\text { PP - Fisher } \\
\text { Chi-square }\end{array}$ & 1,15747 & 0,9977 & $\begin{array}{l}\text { PP - Fisher } \\
\text { Chi-square }\end{array}$ & 18,3312 & 0,0905 \\
\hline \multicolumn{1}{|l|}{ Variabel : Cadangan Devisa } \\
(1 diff)
\end{tabular}

Berdasarkan hasil pengujian dengan bantuan E-Views 10 pada tabel 4.3 diatas menunjukkan bahwa semua variabel dalam penelitian ini yaitu Cadangan Devisa dan Ekspor Lada ternyata tidak stasioner pada tingkat level. Akan tetapi semua variabel tersebut stasioner pada first difference pada taraf signifikan $\alpha=5 \%$ yang berarti bahwa salah syarat dalam pengggunaan model PARDL sudah terpenuhi.

\section{Uji Panjang Lag}

Hasil pengujian Lag Optimum terhadap persamaan PARDL dengan variable bebas Ekspor Lada menunjukkan lag yang optimum adalah lag 3. Terpilihnya Lag 3 berdasarkan pada kriteria sequential modified LR test statistic Final prediction eror (FPE), Akaike information criterion (AIC), Schwarz information criterion (SC) dan Hannan-Quinn information criterion
(HQ), pada taraf nyata $(a=5 \%)$ yaitu sebagai berikut :

Tabel 4.4

Hasil pengujian panjang Lag Optimal

\begin{tabular}{|c|c|c|c|c|c|c|}
\hline Lag & LogL & LR & FPE & AIC & SC & HQ \\
\hline 0 & -1180.994 & NA & $1.22 \mathrm{e}+18$ & 47.31976 & 47.39624 & 47.34888 \\
\hline 1 & -1074.657 & 199.9133 & $2.03 \mathrm{e}+16$ & 43.22628 & $43.45572^{*}$ & 43.31365 \\
\hline 2 & -1070.052 & 8.289812 & $1.99 \mathrm{e}+16$ & 43.20206 & 43.58447 & 43.34768 \\
\hline 3 & -1063.015 & $12.10263^{*}$ & $1.76 \mathrm{e}+16^{*}$ & $43.08061^{*}$ & 43.61597 & $43.28448 *$ \\
\hline 4 & -1060.867 & 3.523507 & $1.91 \mathrm{e}+16$ & 43.15467 & 43.84299 & 43.41679 \\
\hline 5 & -1057.427 & 5.366424 & $1.96 \mathrm{e}+16$ & 43.17707 & 44.01836 & 43.49743 \\
\hline 6 & -1056.933 & 0.730544 & $2.28 \mathrm{e}+16$ & 43.31732 & 44.31157 & 43.69594 \\
\hline 7 & -1052.715 & 5.905003 & $2.29 \mathrm{e}+16$ & 43.30861 & 44.45582 & 43.74547 \\
\hline
\end{tabular}

Sumber : Data diolah, 2020

\section{Uji Koinegrasi}

Pengujian kointegrasi PARDL dalam penelitian menggunakan uji Kao Residual Cointegration Test dan Johansen Fisher Panel Cointegration Test diperoleh hasil sebagai berikut :

\section{Tabel 4.5}

\section{Hasil pengujian Kointegrasi metode KAO}

\begin{tabular}{|l|c|c|}
\hline Method: $\boldsymbol{K}$ AO Residual Cointegration Test & t-Statistic & Prob. \\
\hline ADF & -1.689573 & $\mathbf{0 . 0 4 5 6}$ \\
\hline Residual variance & $1.16 \mathrm{E}+08$ & \\
\hline HAC variance & $1.72 \mathrm{E}+08$ & \\
\hline
\end{tabular}

Sumber : Data diolah, 2020

Hasil pengujian kointegrasi dengan Kao Residual Cointegration Test menunjukkan adanya kointegrasi antara variabel penelitian Cadangan Devisa dan Ekspor Lada, hal ini dilihat dari nilai pvalue sebesar 0,04 (p-value $<0,05$ ). Sedangkan pengujian model Johansen Fisher Cointegration Test diperoleh hasil sebagai berikut.

Tabel 4.6

Hasil pengujian kointegrasi Johansen Fisher Cointegration Test

\begin{tabular}{|c|c|c|c|c|}
\hline \multicolumn{5}{|c|}{ Individual cross section results } \\
\hline \multirow{2}{*}{ Cross Section } & Trace Test & \multirow{2}{*}{ Prob. *** } & Max-Eign Test & \multirow{2}{*}{ Prob.** } \\
\cline { 2 - 4 } & Statistics & & Statistics & \\
\hline Indonesia & $\mathbf{2 0 . 0 2 3 9}$ & 0.2247 & $\mathbf{1 6 . 4 3 2 6}$ & 0.1277 \\
\hline Malaysia & $\mathbf{1 0 1 . 9 0 1 4}$ & 0.0000 & $\mathbf{8 6 . 9 5 1 2}$ & 0.0000 \\
\hline Vietnam & $\mathbf{3 9 . 6 7 8 5}$ & 0.0005 & $\mathbf{2 3 . 1 9 1 3}$ & 0.0133 \\
\hline Brazil & $\mathbf{2 5 . 9 8 5 3}$ & 0.0484 & $\mathbf{1 8 . 4 5 7 1}$ & 0.0679 \\
\hline India & $\mathbf{3 6 . 2 4 0 5}$ & 0.0018 & $\mathbf{2 9 . 2 1 5 6}$ & 0.0014 \\
\hline
\end{tabular}

Sumber : Data diolah, 2020

Berdasarkan hasil pengujian kointegrasi dengan model Johansen Fisher Cointegration Test pada tabel 4.6 diatas, dapat dilihat bahwa nilai Trace Test Statistic > Max-Eign Test yang ada disetiap negara baik Indonesia, Malaysia, Vietnam, Brazil, dan India. Hal ini menanadakan bahwa terjadi 
kointegrasi antara variabel Cadangan Devisa dengan Ekspor lada di 5 negara pengekspor utama lada.

\section{Hasil Estimasi PARDL}

Hasil Pengujian estimasi PARDL dalam jangka panjang dapat diperhatikan pada tabel dibawah ini:

\section{Tabel 4.7}

Hasil Estimasi Panel Autoregressive Distributed Lag (PARDL) Jangka Panjang

\begin{tabular}{|c|r|r|r|r|}
\hline \multicolumn{5}{|c|}{ Long Run Equation } \\
\hline Variable & \multicolumn{1}{c|}{ Coefficient } & Std. Error & t-Statistic & Prob. $^{*}$ \\
\hline EKSPOR LADA & 0.397743 & 0.021562 & 18.44665 & 0.0000 \\
\hline & & & & \\
\hline
\end{tabular}

Sumber : Data diolah, 2020

Adapun rumus persamaan PARDL yaitu:

$$
\Delta \operatorname{CDV}_{\mathrm{j}, \mathrm{t}}=\sum_{\mathrm{i}=1}^{\mathrm{n}} \beta_{1} \mathrm{EKSP}_{\mathrm{j}, \mathrm{t}-1}+\mu_{\mathrm{j}, \mathrm{t}}
$$

Jika dikaitkan rumusan persamaan diatas dengan hasil penelitian PARDL jangka pnajng maka dapat diperoleh hasil sebagai berikut:

$$
\Delta \operatorname{CDV}_{\mathrm{j}, \mathrm{t}}=\sum_{\mathrm{i}=1}^{\mathrm{n}_{1}}+\beta_{1}(0.397) \mathrm{EKSP}_{\mathrm{j}, \mathrm{t}-1}+\mu_{\mathrm{j}, \mathrm{t}}
$$

Berdasarkan hasil pengujian pada tabel 4.7 di atas dapat diperhatikan bahwa variabel ekspor lada dengan menggunakan pendekatan model PARDL berpengaruh secara positif dan siginifikan terhadap cadangan devisa dalam jangka panjang.

Hal ini dapat dilihat dari nilai probabilitas $(0.0000<0.05)$. Nilai Coefficient sebesar $(0.397)$ yang berarti bahwa dalam jangka panjang setiap terjadi kenaikan ekspor lada sebesar 1 satuan maka akan berpengaruh terhadap meningkatnya cadangan devisa sebesar 0.397 satuan, dan sebaliknya apabila ekspor lada menurun maka cadangan devisa juga akan melemah atau mengalami penurunan. Kemudian nilai t-statistik sebesar (18.44665) dengan nilai probabilitas sebesar (0.0000) menunjukkan bahwa variabel ekspor lada memiliki pengaruh secara positif dan signifikan terhadap cadangan devisa.

Selanjutnya dalam jangka pendek hasil estimasi PARDL diperoleh yaitu sebagai berikut:

\section{Tabel 4.8}

Hasil Estimasi Panel Autoregressive Distributed Lag (PARDL) Jangka Pendek

\begin{tabular}{|c|r|r|r|r|}
\hline \multicolumn{5}{|c|}{ Short Run Equation } \\
\hline Variable & \multicolumn{1}{|c|}{ Coefficient } & \multicolumn{1}{c|}{ Std. Error } & \multicolumn{1}{c|}{-Statistic } & \multicolumn{1}{c|}{ Prob.* } \\
\hline COINTEQ 01 & -0.480190 & 0.226909 & -2.116221 & 0.0394 \\
\hline D(CDV(-1)) & 0.290887 & 0.105488 & 2.757543 & 0.0082 \\
\hline D(CDV(-2)) & 0.085358 & 0.160733 & 0.531055 & 0.5978 \\
\hline D(EKSPOR_LADA) & 1.251408 & 1.347790 & 0.928489 & 0.3577 \\
\hline $\begin{array}{c}\text { D(EKSPOR_LADA } \\
(-1))\end{array}$ & 0.891096 & 1.238562 & 0.719460 & 0.4753 \\
\hline $\begin{array}{c}\text { D(EKSPOR_LADA } \\
(-2))\end{array}$ & 0.604249 & 0.835072 & 0.723589 & 0.4728 \\
\hline C & 18157.54 & 15853.60 & 1.145326 & 0.2576 \\
\hline
\end{tabular}

Sumber : Data diolah 2020

Adapun rumus persamaan PanelARDL dalam jangka pendek yaitu :

$$
\begin{gathered}
\Delta \mathrm{CDV}_{\mathrm{j}, \mathrm{t}}=\alpha_{0 \mathrm{i}}+\sum_{i=1}^{n} \alpha 1 \mathrm{i} \Delta \mathrm{CDV}_{\mathrm{j}, \mathrm{t}-1}+\sum_{i=1}^{n} \alpha 2 \mathrm{i} \\
\Delta \mathrm{EKSP}_{\mathrm{j}, \mathrm{t}-1}+\mu_{\mathrm{j}, \mathrm{t}}
\end{gathered}
$$

Jika dikaitkan dengan hasil PARDL yang diperoleh dalam penelitian ini yaitu :

$$
\begin{gathered}
\Delta \mathrm{CDV}_{\mathrm{j}, \mathrm{t}}=18157.54+(0.290) \Delta \mathrm{CDV}_{\mathrm{j}, \mathrm{t}-1}+(1.251) \\
\Delta \mathrm{EKSP}_{\mathrm{j}, \mathrm{t}-1}+\mu_{\mathrm{j}, \mathrm{t}}
\end{gathered}
$$

Berdasarkan hasil penelitian pada tabel 4.8 diatas terlihat bahwa dalam jangka pendek ekspor lada tidak berpengaruh secara positif dan tidak signifikan terhadap cadangan devisa di 5 negara pengekspor utama lada. Hal ini terlihat dari nilai probabilitas $(0.3577>0.05)$.

Nilai Coefficient sebesar (18157.54) yang berarti bahwa apabila ekspor lada bernilai konstan maka cadangan devisa bernilai konstan sebesar US\$ 18157.54 milyar. Nilai Coefficient sebesar (1.251) yang berarti apabila dalam jangka pendek ekspor lada meningkat sebesar 1 satuan maka cadangan devisa akan meningkat sebesar 1.251 satuan. Selanjutnya, dalam jangka pendek perubahan atau perkembangan dari cadangan devisa yang terjadi tahun sekarang sebesar (US\$ 0.290 milyar) dipengaruhi oleh cadangan devisa pada tahun sebelumnya sebesar (US\$ 0.085 milyar), begitu juga pada perkembangan ekspor lada tahun sekarang sebesar (0.891 Ton) yang dipengaruhi oleh perkembangan ekspor lada tahun sebelumnya sebesar (0.604 Ton).

Koefisien jangka pendek dengan adanya nilai uji lag memberikan hasil yang berbeda. Variabel Cadangan Devisa lag 2 bertanda positif namun tidak signifikan sebesar (0.531 dengan probablitas sebesar 0.597), lag 1 juga bertanda positif dan signifikan sebesar (2.757 dengan probablitias 0.008) memberikan arti bahwa perubahan yang 
terjadi pada cadangan devisa dari lag 2 menuju lag 1 mengalami perubahan yang sangat baik, dimana terjadi peningkatan terhadap cadangan devisa dari angka (0.531) menuju kepada angka (2.57) dengan kestabilan menuju signifikansi yang diharapkan yaitu sebesar (0.008), dalam hal ini terlihat bahwa semua negara pengekspor utama lada terus berusaha meningkatkan sumber pendapatan devisa negaranya.

Selanjutnya, variabel ekspor lada dengan pendekatan PARDL jangka pendek menggunakan lag 2 dan lag 1 juga memberikan hasil yang berbeda, dimana lag 2 bertanda positif namun tidak signifikan dengan nilai sebesar $(0.723$ dan probabilitas sebesar 0.472 ), lag 1 bernilai positif dan tidak signifikan dengan angka sebesar (0.719 dengan probabilitas 0.475) yang artinya perkembangan ekspor lada di lima negara pengekspor utama lada dalam jangka pendek mengaalami perkembangan atau perubahan yang tidak efektif, hal ini terlihat dari nilai lag 2 (0.723) mengalami penurunan menuju lag 1 (0.719) dengan tingkat stabilitas yang tidak signifikan, namun penurunan yang terjadi tidak terlalu tajam hanya menurun sekitar $4 \%$, hal ini terjadi karena pada perkembangan ekspor lada ada tiga negara yang mengalami penurunan ekspor ladanya, ke-tiga negara tersebut yaitu Indonesia, Malasia, dan India.

Nilai ECT/Cointeq 01 bertanda negatif dan siginifikan seebesar (-0.480 dengan probabiitas 0.03 ) yang artinya variabel Cadangan Devisa dan ekspor lada sedang mengalami penyesuaian keseimbangan dari jangka pendek menuju keseimbangan jangka panjang dengan tingkat penyesuaian kecepatan sekiar $48,01 \%$ per tahun.

\section{Pembahasan}

\section{Daya Saing Ekspor Lada di 5 Negara Pengekspor Utama Lada}

Berdasarkan data ekspor lada dari Pepper International Community (IPC) menyebutkan negara Vietnam menduduki peringkat nomor satu pada kategori negara pengekspor lada terbesar di dunia dengan jumlah ekspor sebesar 2.015.143 Ton dalam periode waktu 2001-2017, peringkat kedua diduduki oleh negara Indonesia, dan ketiga oleh negara Brazil, keempat negara India, dan kelima negara Malaysia.

Sedangkan berdasarkan pengujian indeks RCA pada tabel 4.2 menunjukan hasil negara Vietnam sebagai negara yang juga menduduki peringkat pertama dengan nilai RCA sebesar 1,2631, negara Brazil yang menduduki posisi kedua dengan nilai RCA sebesar 1,1369, dan posisi ketiga diraih oleh negara Indonesia dengan hasil RCA sebesar 0.6114. Hasil penelitian juga tidak sejalan dengan dugaan hipotesis, sehingga terima (H0) dan tolak (H1) yang berarti bahwa tidak semua negara pengekspor utama lada mempunyai daya saing diatas rata-rata berdasarkan pengujian indeks RCA, hanya terdapat dua negara yang memiliki keungggulan komperatif diatas ratarata yaitu negara Vietnam dan Brazil, selanjutnya negara yang lain masih dalam tahap penyesuaian untuk meningkatkan daya saing negaranya, seperti negara Indonesia, Malaysia dan India.

Hasil indeks RCA juga menyatakan bahwa negara Vietnam dengan peringakat pertama sebagai negara yang mampu menguasai pasar ekspor lada di dunia. Penelitian ini juga didukung oleh (Yurike, 2017) yang menyatakan bahwa ekspor lada negara Vietnam lebih tinggi dibandingkan ekspor lada negara lainnya di dunia.

Hasil penelitian ini juga sependapat dengan penelitian yang dilakukan(Nurhayati et al., 2018) yang meneliti tentang pengembangan daya saing ekspor lada Indonesia menyatakan bahwa dari hasil perhitungan RCA negara Vietnam memiliki nilai RCA lebih tinggi dari pada negara Indonesia, hal ini berarti negara Vietnam merupakan snegara yang mampu menguasai pasar lada dunia. Penelitian yang dilaksanakan oleh (Feira Aprilia, R, 2013) juga menyatakan bahwa negara Vietnam merupakan negara yang memperoleh rangking RCA tertinggi, hal ini dibuktikan dari hasil perhitungan RCA pada tahun 2013, yang mana RCA negara Vietnam sebesar $(44,77)$, Indonesia berada diposisi kedua dengan nilai RCA $(17,26)$, negara Brazil diurutan ketiga dengan nilai RCA sebesar $(7,70)$ India diposisi ke empat dengan nilai RCA $(3,60)$, dan Malaysia berada diposisi terkahir dengan nilai sebesar RCA $(3,13)$.

\section{Pengaruh Eskpor Lada Bagi Cadangan Devisa di 5 Negara Pengekspor Utama Lada dengan Pendekatan Model Panel Autoregressive Distributed Lag (PARDL)}

Berdasarkan hasil pengujian PARDL pada ekspor lada terhadap cadangan devisa pada 5 negara pengekspor utama lada dapat disimpulkan bahwa ekspor lada berpengaruh secara positif dan signifikan terhadap cadangan devisa, hal ini dapat dilihat dari nilai probabilitas sebesar $(0.0000<$ 0.05 ) yang berarati bahwa hasil dari ekspor lada 5 negara pengekspor utama lada memberikan kontribusi dalam jangka panjang kepada cadangan devisa di masing-masing negaranya. Hasil penelitian ini juga sesuai dengan dugaan hipotesis yang menyatakan bahwa ekspor lada memiliki 
pengaruh terhadap cadangan devisa di lima negara pengekspor utama lada, sehingga tolak (H0) dan terima (H1) yang mana dalam jangka panjang perkembangan ekspor lada memberikan kontribusi terhadap cadangan devisa di lima negara pengekspor utama lada.

Berpengaruhnya ekspor lada dalam jangka panjang terhadap cadangan devisa dapat diartikan bahwa setiap peningkatan ekspor lada disetiap tahunnya memberikan kontribusi yang baik bagi cadangan devisa di setiap negaranya. Oleh karena itu setiap negara di dunia terus berusaha meningkatkan kegiatan ekspornya dengan tujuan nantinya mendapatkan nilai tambah dari kegiatan internasional tersebut yang kemudian dapat meningkatkan pendapatan negaranya yang berupa cadangan devisa.

Penelitian ini juga didukung oleh penelitian yang dilakukan (Silitonga Dear, 2015) menyatakan bahwa dalam jangka panjang ekspor mempengaruhi cadangan devisa secara signifikan, selanjutnya (Agustina, 2014) dengan hasil penelitiannya menyebutkan bahwa ekspor berpengaruh secara positif dan signifikan terhadap cadangan devisa. Kemudin penelitian yang dilakukan oleh (Jimmy, 2013) yang menyatakan bahwa ekspor berpengaruh secara signifikan terhadap cadangan devisa dalam jangka panjang. Hasil ini juga diperkuat oleh teori cadangan devisa, yang menyebutkan bahwa cadangan devisa yang dimiliki suatu negara dipengaruhi oleh transaksi berjalan dan kegaitan ekspor, yang berarti bahwa laju perkembangan ekspor yang tinggi dapat memperkuat Cadangan devisa. Sehingga apabila ekspor mengalami peningkatan maka cadangan devisa juga akan ikut meningkat.

Selanjutnya dalam jangka pendek, hasil pengujian PARDL menunjukkan bahwa ekspor lada tidak berpengaruh secara positif dan tidak signifikan terhadap cadangan devisa di 5 negara pengekspor utama lada, hal ini dapat dilihat dari nilai probabilitas sebesar $(0.3577>0.005)$ yang berarti bahwa secara jangka pendek ekspor lada tidak memberikan pengaruh terhadap cadangan devisa di 5 negara pengekspor utama lada.

Penelitian ini dalam jangka pendek tidak memberikan pengaruh secara positif terhadap cadangan devisa disebabkan karena dalam jangka pendek ekspor lada bisa mengalami penurunan atau kenaikan sehingga disetiap negara tidak selalu memiliki jumlah ekspor lada yang sama. Ada negara pengeskpor lada yang setiap tahunnya terus mengalami peningkatan, namun ada pula negara yang bahkan mengalami penurunan ekspor lada yang darastis sehingga dalam jangka pendek tidak memberikan kontribusi yang baik terhadap cadangan devisa di masingmasing negaranya.

Hasil penelitian dalam jangka pendek juga tidak signifikan dan tidak sejalan dengan teori cadangan devisa yang menyatakan bahwa ekspor memiliki posisi penting dalam perkembangan cadangan devisa setiap negara, namun hasil penelitian tidak signifikan disebabkan karena adanya perbedaan tingkat ekspor lada diantara kelima negara pengekspor utama lada tersebut, kemudian tidak berpengaruhnya ekspor dalam jangka pendek terhadap cadangan devisa bukan berarti cadangan devisa yang dimiliki suatu negara tipis, tetapi kontribusi yang diberikan dari ekspor lada terhadap cadangan devisa tersebut lemah, karena ekspor yang dimaksud dalam teori yaitu total ekspor keseluruhan barang dan jasa yang dimiliki suatu negara bukan hanya dari salah satu komoditas.

Hasil penelitian ini sejalan dengan penelitian yang dilakukan, (Asmara, 2018) yang menyatakan bahwa dalam jangka pendek ekspor tidak berpengaruh secara positif dan tidak signifikan terhadap cadangan devisaa, kemudian (Uli, 2016) menyatakan bahwa tidak terdapat pengaruh secara signifikan dari ekspor terhadap cadangan devisa.

\section{KESIMPULAN DAN REKOMENDASI Kesimpulan}

Berdasarkan hasil penelitian maka diperoleh kesimpulan sebagai berikut :

1. Berdasarkan perhitungan indeks RCA diperoleh hasil bahwa negara Vietnam merupakan negara pengekspor lada terbesar di dunia dan mampu memegang kendali atau menguasai ekspor lada di pasar dunia, atau disebut sebagai negara yang memiliki keunggulan komperatif tinggi dengan nilai indeks RCA sebesar 1.2631 yang juga sebagai negara yang mampu mengusai pasar dunia ekspor lada, kemudian disusul oleh negara Brazil pada peringkat kedua dengan nilai RCA sebesar 1.136, Negara Indonesia berada diurutan ketiga dengan hasil RCA sebesar 0.6114, negara India berada diurutan keempat dengan nilai sebesar 0.5596 dan diurutan kelima yaitu negara India dengan nilai RCA sebesar 0.5375 .

2. Berdasarkan perhitungan Panel Autoregressive Distributed Lag (PARDL) diperoleh hasil dalam jangka panjang ekspor lada memberikan kontribusi pengaruh secara positif dan 
signifikan terhadap cadangan devisa. Hal ini dapat dilihat dari nilai nilai probabilitas sebesar $(0.0000<0.05)$ yang berarati bahwa hasil dari ekspor lada di 5 negara pengekspor utama lada memberikan kontribusi kepada cadangan devisa di masing-masing negaranya.

3. Secara jangka pendek hasil pengujian PARDL menunjukkan bahwa ekspor lada tidak berpengaruh secara positif dan tidak signifikan terhadap cadangan devisa di 5 negara pengekspor utama lada, hal ini dapat dilihat dari nilai probabilitas sebesar $(0.3577$ $>0.05$ ) yang berarti bahwa ekspor lada tidak memberikan pengaruh atau kontribusi terhadap cadangan devisa di 5 negara pengekspor utama lada.

\section{Rekomendasi}

Berdasarkan kesimpulan diatas maka saran yang dapat penulis berikan yaitu:

1. Bagi negara yang masih tertinggal dalam keunggulan daya saingnya dapat lebih meningkatkan kembali kualitas eskpor ladanya agar mampu bertahan dipersaingan pasar internasional, terutama negara Indonesia yang tercatat memiliki ekspor lada lebih banyak dari negara Brazil, dalam hal ini negara Indonesia perlu mengklarifikasi kembali ekspor ladanya agar nantinya ekspor lada indonesia bukan hanya sebatas ekspor terbanyak namun juga mampu mengalahkan negara lainnya dalam persaingan pasar internasional.

2. Ekspor lada yang ada disetiap negara harus terus ditingkatkan kualitas dan kuantitasnya agar dapat memberikan sumbangan kontribusi yang besar bagi setiap negaranya. Karena devisa sangatlah diperlukan bagi setiap negara dan juga tingkat devisa memiliki peranan penting dalam perekonomian. Terutama bagi negara-negara yang tidak memilki pengaruh siginifikan terhadap cadangan devisa, dalam hal ini harus lebih diperhatikan kembali perkembangan ekspor lada masing-masing

\section{DAFTAR PUSTAKA}

Agustina, R. (2014). Pengaruh Nilai Ekspor, Nilai Impor, Nilai Tukar Rupiah, Dan Tingkat Inflasi Terhadap Cadangan Devisa Indonesia. Jurnal Wira Ekonomi Mikroskil, 04(02), 61-70.

Alamsyah Zulkifli, M. A. (2019). Analisis Komparasi Daya Saing Ekspor Lada Indonesia Terhadap Vietnam Dan Malaysia Di Pasar Asean. Jurnal Ilmiah Sosio Ekonomika Bisnis, 22(1), 80-90.

Apriyanto, D. (2016). Analisis faktor-faktor yang mempengaruhi return indeks harga saham gabungan (ihsg) di indonesia: pendekatan model ardl.

Apsari, M. (2018). Analisis pengaruh ekspor, impor, nilai tukar rupiah terhadap cadangan devisa indonesia. Jurnal Ekonomi Pembangunan, 05(04), 1-14.

Asmanto, P., \& Suryandari, S. (2008). Cadangan Devisa, Financial Deepening Dan Stabilisasi Nilai Tukar Riil Rupiah Akibat Gejolak. Buletin Ekonomi Moneter Dan Perbankan, 10(2), 1-35.

Asmara, F. C. R. (2018). Analisis Pengaruh Ekspor, Impor, Kurs, Inflasi Dan Utang Luar Negeri Terhadap Cadangan Devisa Indonesia Periode Januari 2014-September 2017. Jurnal Ekonomi Pembangunan, 01(09), $1-16$.

Athiyah, F. N. U. R. (2018). Analisis Tingkat Daya Saing Lada Indonesia Di Pasar Asia. Jurnal Agribisnis, 13(02).

Case, K. E. (2007). Prinsip-Prinsip Ekonomi Edisi kedelapan. Jakarta: Erlangga

Dananjaya Baskara, jayawarsa, P. S. (2019). Pengaruh Ekspor, Impor, Kurs Nilai Tukar Rupian, Dan Tingkat Inflasi Terhadap Cadangan Devisa Indonesia Periode 1999. 2018. Warmadewa Economic Development Journal, 2(2), 64-71.

Feira Aprilia, R, A. Za. (2013). Indonesia Dalam Menghadapi Globalisasi (Studi Pada Ekspor Lada Indonesia Tahun 2009-2013 ). Jurnal Administrasi Bisnis, 27(2), 1-7.

Gandhi, Virgoana, D. (2006). Pengelolaan 
Cadangan Devisa di Bank Indonesia (Issue 17).

Hani Zaun, Pujiantio Agung, T. E. (2016).

Pengaruh Ekspor Impor Terhadap

Cadangan Devisa Negara Studi Pada

Komoditi Lada. Jurnal Ekonomi \& Kebijakan Publik, 07(03), 1-12.

Hidayat, D. (2018). Kemampuan Panel

Autoregressiv Distributed Lag Dalam Memprediksi Fluktuasi Saham Property And Real Estate Indonesia. Jurnal Kajian Ekonomi Dan Kebijakan Publik, 3(2). https://doi.org/10.1051/matecconf/20171210 7005

Jimmy, B. (2013). Ekspor Dan Impor Pengaruhnya Terhadap Posisi Cadangan Devisa Di Indonesia. Jurnal EMBA, 1(4), 1406-1415.

Mainah, A. (2016). Analisis Pengaruh Ekspor dan Impor terhadap Cadangan Devisa Indonesia. Journal of Chemical Information and Modeling, 53(9), 1689-1699. https://doi.org/10.1017/CBO9781107415324 Marlinda, B. (2008). Analisis Daya Saing Lada Indonesia Di Pasar Internasional. Skripsi Fakultas Ekonomi, Univ.Negeri Makasar

Munandar, B. \&. (2010). Dasar-dasar ekonomi internasional (Pengelolaan dan aplikasi metode kuantatif). jakarta: Prenanda Media Group.

Noaliana Ade, Sari Indah, Wahyu, R. (2018). Kemampuan Panel Auto Regressive Distributed Lag Dalam Mendeteksi Transmisi Moneter Negara Brici -. Jurnal Kajian Ekonomi Dan Kebijakan Publik, 03(02), 1-16.

Nopirin, P. (2014). Ekonomi Internasional (cetakan ke-06 ed.). Yogyakarta: Pustaka BPFE

Nurhayati, E., Hartoyo, S., \& Mulatsih, S. (2018).

Pengembangan Pasar Ekspor Lada Indonesia. Buletin Ilmiah Litbang Perdagangan, 12(02), 267-288.

Pinem, J. R. (2009). Analisis Pengaruh Ekspor, Impor, Kurs Nilai Tukar Rupiah Terhadap Cadangan Devisa Indonesia. Jurnal Ekonomi Pembangunan, Univ. Sumatera Utara.
Rahmat Hidayat,Irawan, N. A. (2018). Kemampuan Panel Auto Regressiv Distributed Lag Dalam Memprediksi Fluktuasi Saham Property And Real Estate Indonesia. Jurnal Kajian Ekonomi Dan Kebijakan Publik, 3(2), 133-149.

Ridho, M. (2015). Pengaruh Ekspor , Hutang Luar Negeri Dan Kurs Terhadap Cadangan Devisa Indonesia. E-Jurnal Perdagangan, Industri, Dan Moneter, 3(1), 1-9.

Satryana, Hardi, M. (2016). Analisis Daya Saing Ekspor Teh Indonesia Ke Pasar Asean Periode 2004-2013. E-Jurnal EKonomi Pembangunan, 05(05), 598-613.

Silitonga Dear, R. (2015). Analisis Pengaruh Ekspor, Impor Dan Nilai Tukar Rupiah Terhadap Cadangan Devisa Indonesia Dengan Metode Error Correction Mechanism Periode 2009-2014. Jurnal Ekonomi Pembangunan, 07(02), 1-25.

Tambunan, T. (2001). Perdagangan Internasional dan Neraca Pembayaran (Teori \& Impiris). Jakarta: Ghalia Indonesia.

Uli, L. B. (2016). Analisis Cadangan Devisa Indonesia. Jurnal Perspektif Pembiayaan Dan Pembangunan Daerah, 4(1), 15-24.

Ustriaji Farid. (2016). Analisis Daya Saing Komoditi Ekspor Unggulan Indonesia Di Pasar Internasional. Jurnal Ekonomi Pembangunan, 04(02), 1-12.

Yurike, A. (2017). Analisis Komparasi Daya Saing Ekspor Lada Indonesia Terhadap Vietnam Dan Malaysia Di Pasar Asean. Jurnal Agribisnis, 08(03), 1-15. 